\title{
Population dynamic of the Spanish ibex Capra pyrenaica in Sierra Nevada Natural Park (southern Spain)
}

\author{
Jesús M. PÉREZ, José E. GRANADOS and Ramón C. SORIGUER
}

\begin{abstract}
Pérez J. M., Granados J. E. and Soriguer R. C. 1994. Population dynamic of the Spanish ibex Capra pyrenaica in Sierra Nevada Natural Park (southern Spain). Acta theriol. 39: 289-294.

The whole area of distribution of the Spanish ibex Capra pyrenaica Schinz, 1838 population of Sierra Nevada Natural Park was surveyed for the first time during July-August 1993 and the densities were estimated by using the line transects method. A mean density of $7.69 \pm 0.50$ ibexes $/ \mathrm{km}^{2}$ was obtained, with sex ratio (males/ /females) of 0.80 and kids/adult females rate of 0.39 . Data on size and composition of groups and on altitudinal distribution are also included. The demographic trend of ibexes in Sierra Nevada during last 30 years is reconstructed on the basis of data referred to the National Game Reserve, located within our study area.

Estación Biológica Doñana (CSIC), Unidad de Biología Aplicada, Biología de Especies Cinegéticas y Plagas, P.O. Box 1056, 41080 Sevilla (JMP, RCS); Agencia de Medio Ambiente, Dirección Provincial de Granada, Gran Vía de Colón 48, 18010 Granada (JEG), Spain
\end{abstract}

Key words: Capra pyrenaica, summer census, line transects, Sierra Nevada, Spain

\section{Introduction}

Although there still exists certain disagreement with regards to the taxonomic status of the Spanish ibex, because morphological and biometric features (Cabrera 1911) are contrary to preliminary data obtained by starch gel electrophoresis analysis (Nadlinger et al. 1992), it is generaly considered amongst zoologists and hunters that Capra pyrenaica Schinz, 1838 is an Iberian endemic species.

With respect to the ibex of southern Spain, the population from Cazorla, Segura y Las Villas range of mountains is one of the best known (Fandos 1986, 1991). On the contrary, data on the biology and ecology of ibexes from Sierra Nevada are scarce and fragmented; they are restricted to some concrete parts of this area such as the National Game Reserve and a zone measuring $30 \mathrm{~km}^{2}$ in eastern Sierra Nevada (Rodríguez 1969, Alados 1985b, Escos 1988, Fandos 1989, 1991, Martínez $1988,1990)$. In order to establish an adequate plan of management for this population we have started to study it in its entirely, begining at the demographic level. 


\section{Study area}

The survey of density of Capra pyrenaica was carried out in the Sierra Nevada Natural Park, which has an extent of $1690 \mathrm{~km}^{2}$ and comprises the alpine massif with the highest peak of the Iberian Peninsula, the Mulhacén $(3481 \mathrm{~m})$ and eleven more peaks higher than $3000 \mathrm{~m}$. Because of its latitudinal position $\left(37^{\circ} \mathrm{N}\right)$ and its proximity to the Mediterranean sea, Sierra Nevada shows a mediterranean climate with important altitudinal gradients of temperature and rainfall, all the bioclimatic stages described for this climate being present. Much of the natural vegetation of these mountains has been continuously altered by human activities so as to become relict. Nevertheless the flora of Sierra Nevada is still rich, comprising over 2000 species of plants with a high number of endemic species amongst them (Valle 1985).

Figure 1 shows the geographic location of Sierra Nevada Natural Park, and delimits the National Game Reserve, a $354 \mathrm{~km}^{2}$ area protected since 1968.
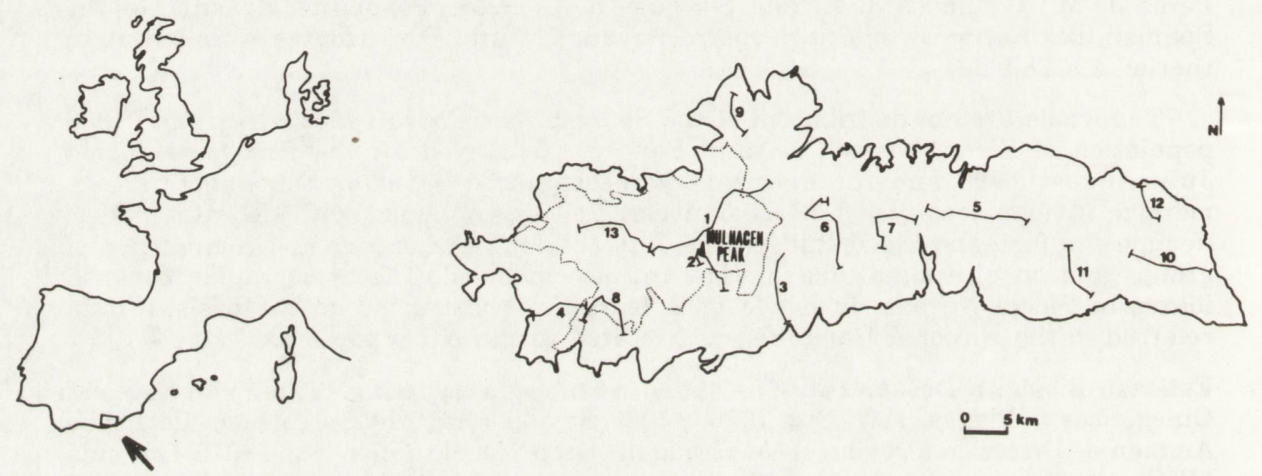

Fig. 1. Geographical location of the Sierra Nevada Natural Park in southern Spain and location of transects sampled within the Sierra Nevada Natural Park. Discontinuous line indicates the limit of the National Game Reserve.

\section{Material and methods}

Survey was carried out during July and August 1993, by means of the line transects method (Anderson et al. 1979, Burnham et al. 1980, Buckland et al. 1993). Thirteen transects (Fig. 1), with a total length of $135.2 \mathrm{~km}$ and ranging from 400 to $3484 \mathrm{~m}$ in altitude were walked by two-three persons at a mean speed of $1.5 \mathrm{~km} / \mathrm{h}$, between $07.00 \mathrm{am}$ and $09.00 \mathrm{pm}$. Perpendicular distances of animals observed to the line transect were groupped into $50 \mathrm{~m}$ intervals for statistical treatment of data, which was carried out by means of the program DISTANCE (Laake et al. 1993). For density estimation the Fourier Series estimator was selected.

Sex and age of each animal observed were recorded too. The demographic trend of the ibex population in the National Game Reserve was obtained on the basis of available data from scientific papers and official censuses from the area.

\section{Results}

A total of 415 ibexes were observed during the census period and data on perpendicular distances were compared to those theoretical ones provided by the model by means of $\chi^{2}$-test. 
Table 1. Age classes within male Capra pyrenaica (yearlings are ommited).

\begin{tabular}{llrr}
\hline Age classes & & \multicolumn{3}{c}{ Number $(\%)$} \\
\hline Youngs: & $1-2 \mathrm{yr}$ & 36 & $(23.2)$ \\
Subadults: & $3-4 \mathrm{yr}$ & 73 & $(47.1)$ \\
Adults: & $5-6 \mathrm{yr}$ & 22 & $(14.2)$ \\
& $7-8 \mathrm{yr}$ & 10 & $(6.5)$ \\
Olds: & $>8 \mathrm{yr}$ & 14 & $(9.0)$ \\
Total & & 155 & $(100.0)$ \\
\hline
\end{tabular}

Table 2. Frequencies of different kinds of groups of Capra pyrenaica.

\begin{tabular}{lcc}
\hline Kind of group & $\begin{array}{c}\text { Number of } \\
\text { observations }\end{array}$ & Percentage \\
\hline Single individuals & 22 & 26.8 \\
Youngs & 0 & 0.0 \\
Males & 12 & 14.6 \\
Females & 11 & 13.4 \\
Females with kids & 31 & 37.9 \\
Mixed groups & 6 & 7.3 \\
Total & 82 & 100.0 \\
\hline
\end{tabular}

A density of $7.69 \pm 0.50$ ibexes $/ \mathrm{km}^{2}$ was obtained, with a variation coefficient of $6.4 \%$. Thus, we have a total population of about 13000 ibexes in the Sierra Nevada Natural Park (95\% confidence interval: 11370-14660).

With regards to sex, 155 males older than 1 year and 192 females, of which 175 were adult, were observed. Only 69 yearlings were detected. Thus, we have a sex ratio (males/females) of 0.8 and a reproductive index (kids/adult females) of 0.39 . An age pyramid for males was obtained as included in Table 1.

During this study a total number of 82 observations, both with single individuals and groups were made (Table 2). Groups size ranged from 2 to 33 animals, with a mean value of 7 ibexes/group. Generally, groups of males were greater than the remaining kinds of groups. Nevertheless groups of females with kids were the most frequently observed. According to the altitudinal distribution over $95 \%$ of ibexes were observed in altitudes over $2000 \mathrm{~m}$ (Table 3), mainly in the highest peaks and surrounding areas, which are located within the National Game Reserve. Transects number 1, 2, 8 and 13 are located within this area. When

Table 3. Altitudinal distribution of Capra pyrenaica specimens observed in Sierra Nevada during survey.

\begin{tabular}{ccccc}
\hline Altitudinal range $(\mathrm{m})$ & Length $(\mathrm{km})$ & $n$ of ibexes & $\%(n=415)$ & inds $/ \mathrm{km}$ \\
\hline $500-750$ & 1.6 & 0 & 0 & 0 \\
$750-1000$ & 7.2 & 0 & 0 & 0 \\
$1000-1250$ & 12.2 & 4 & 0.9 & 0.3 \\
$1250-1500$ & 5.3 & 0 & 0 & 0 \\
$1500-1750$ & 5.2 & 0 & 0 & 0 \\
$1750-2000$ & 14.4 & 9 & 2.2 & 0.6 \\
$2000-2250$ & 21.2 & 20 & 4.8 & 0.9 \\
$2250-2500$ & 34.5 & 88 & 21.2 & 2.6 \\
$2500-2750$ & 10.7 & 44 & 10.6 & 4.1 \\
$2750-3000$ & 6.1 & 90 & 21.7 & 14.7 \\
$3000-3250$ & 14.8 & 111 & 26.7 & 7.5 \\
$3250-3481$ & 2.0 & 49 & 11.8 & 24.5 \\
\hline
\end{tabular}


we grouped data from these transects we obtained a density of 20.6 ibexes $/ \mathrm{km}^{2}$ $\left(\mathrm{ES}=1.91, \mathrm{CV}=9.3 \%, 95 \%\right.$ confidence interval: $\left.16.9-24.4 \mathrm{ibexes} / \mathrm{km}^{2}\right)$. In the reserve the number of animals recorded reached almost $80 \%$ of the total observed. Since 1960 the population in this area has been continuously increasing, rising densities over 20 ibexes $/ \mathrm{km}^{2}$ in 1993. This growth curves fit to the function $\mathrm{DEN}=B[\operatorname{EXP}(A \times t)]$, where DEN means density, $B$ and $A$ are parameters of the function $(A=0.1017, B=-199.8)$, and $t$ is the time in years.

\section{Discussion}

The summer is the best and, in the practice, the only season in which the whole ibex population of Sierra Nevada can be censused because the absence of snow allows accesibility to all areas of this Natural Park simultaneously. Moreover, during other seasons a large number of ibexes descend to lowland areas (forested zones) where visibility is considerably less. The use of other census methods here, such as the pellet group technique, would decrease the accuracy of results because of the presence of domestic sheep and goats and the similarity of their pellets and to those of ibexes.

The unpredictable variations of climate and availability of food, typical of the mediterranean climate, involve a high risk that females will be barren as well as a heavy mortality of mothers, embryos and kids (Alados and Escos 1985, Fandos 1989). The proportion of females with kids observed during this study seems to be too small, if we take into account a fecundity rate of 0.83 for this species (Fandos 1991). The value observed in our study might be considered as a measure of reproductive success and agrees with data given by Alados and Escos (1985) and Fandos (1986) just before the decline of the ibex population in Cazorla range (southern Spain).

Size and structure of groups were similar to those shown by other Sparish ibex populations at this time of year (González 1982, Alados 1985a, Fandos 1991). With regards to the altitudinal distribution, it seems to be influenced by the presence of fresh pastures in the higest peaks area during the summer.

We must take into account the altitudinal seasonal movements of ibexes which can produce relevant fluctuations in local density. Other factors, like human pressure (Escos 1988) or competition with domestic sheep (Martinez 1990) also have an influence on ibexes distribution and density at particular locations. Nevertheless, when we consider the data overall they become statistically consistent and more realistic.

The population of Spanish ibex in Sierra Nevada was dwindling in 1936 (Alados $1985 \mathrm{~b}$ ), although its size has been continuously increasing since the cration of the National Game Reserve. The absence of predators, inadequate management of the species, together with the decrease of furtive hunting seem to be the causes for the actual status of this ungulate in this natural park. Since a populition can 


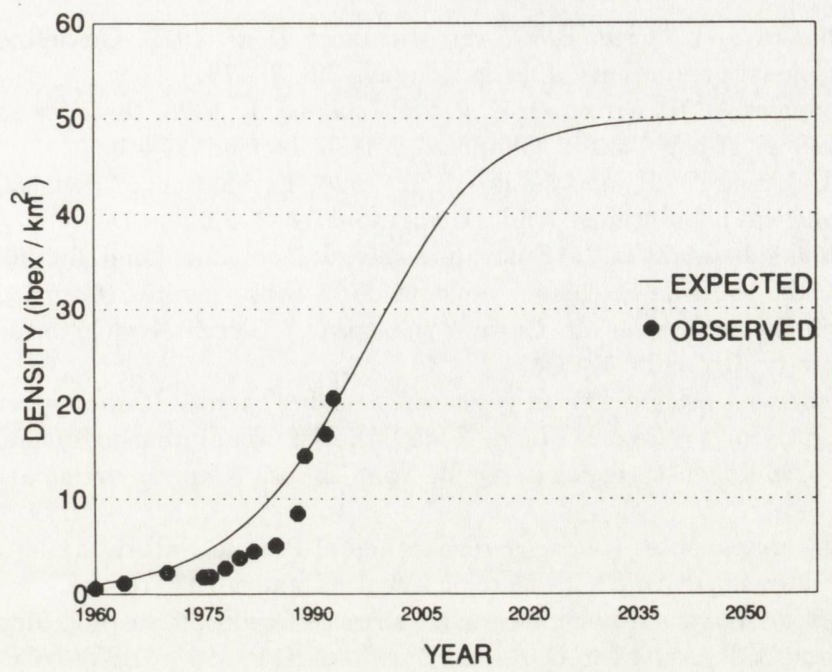

Fig. 2. Demographic trend of Capra pyrenaica in the Sierra Nevada Natural Park during last decades and future density values expected.

not be increasing indefinitely, when we fit the trend of ibexes population in Sierra Nevada with its actual growth rate $r=0.102$ and a theoretical asymptote of 50 ibexes $/ \mathrm{km}^{2}$ (Fig. 2) we obtain that about yr 2010 this value would be reached. The expected density value, given by this logistic model for 1993 is 19.6, which is similar to that obtained in this study. At present density is similar to that observed in the Cazorla Range Mountains before an outbreak of sarcoptic mange produced over $75 \%$ of mortality of ibexes. Because the population is still rising and scabiosis cases have started to be observed, natality is low and there are high densities of domestic ungulates (Agencia de Medio Ambiente 1993) that exert a strong feeding competence with the ibex (Martínez 1988), we guess that this population is in a previous step to a high mortality process. Time will confirm it.

Acknowledgements: The authors wish to thank to M. Moreno, C. Franco, J. M. Gil and F. Gómez for their collaboration in the field work. This study has been partially supported by the Agencia de Medio Ambiente. Frogram DISTANCE and the associated User's Guide was kindly suplied by its authors.

\section{References}

Alados C. L 1985a. Group size and composition of the Spanish ibex (Capra pyrenaica Schinz) in the Sierras of Cazorla and Segura. [In: The biology and management of mountain ungulates. S. Lovari, ed]. Croom Helm, London: 134-147.

Alados C. L 1985b. Distribution and status of the Spanish ibex (Capra pyrenaica Schinz). [In: The biology and management of mountain ungulates. S. Lovari, ed]. Croom Helm, London: 204-211.

Alados C. L. and Escos J. 1985. La cabra montés de las Sierras de Cazorla y Segura. Una introducción al estudo de sus poblaciones y comportamiento. Naturalia Hispanica 28: 1-36.

Agencia de Medio Ambiente 1993. Censo y status poblacional de la cabra montés en el Parque Natural de Sierrı Nevada, Granada. Technical inform. A.M.A., Granada: 1-32. 
Anderson D. R., Laake J. L., Cran B. R. and Burnham K. P. 1979. Guidelines for line transect sampling of biological populations. J. Wild. Manage. 43: 70-78.

Buckland S. T., Anderson D. R., Burnham K. P. and Laake J. L. 1993. Distance sampling: estimating abundance of biological populations. Chapman \& Hall, London: 1-440.

Burnham K. P., Anderson D. R. and Laake J. L. 1980. Estimation of density from line transect sampling of biological populations. Wild. Monographs 72: 1-202.

Cabrera A. 1911. The subspecies of the Spanish ibex. Proc. zool. Soc. Lond. 30: 963-977.

Escos J. 1988. Estudio sobre la ecología y etología de la cabra montés (Capra pyrenaica hispanica Schimper, 1848) de las sierras de Cazorla y Segura y Sierra Nevada oriental. Ph. D. thesis. Granada University, Granada: 1-604.

Fandos P. 1986. Aspectos ecológicos de la población de cabra montés (Capra pyrenaica Schinz, 1838) en las sierras de Cazorla y Segura (Jaen). Ph. D. thesis, Complutense University, Madrid: 1-460.

Fandos P. 1989. Reproductive strategies in female Spanish ibex (Capra pyrenaica). J. Zool., Lond. 218: 339-343.

Fandos P. 1991. La cabra montés (Capra pyrenaica) en el Parque Natural de las Sierras de Cazorla, Segura y Las Villas. ICONA-CSIC, Colección Técnica, Madrid: 1-176.

González G. 1982. Eco-ethologie du bouquetin en Sierra de Gredos. Acta Biol. Montana 1: 177-215.

Laake J. L., Buckland S. T., Anderson D. R. and Burnham K. P. 1993. DISTANCE Version 2.0. User's Guide. Colorado Cooperative Fish \& Wildlife Research Unit, Colorado State University, Colorado: 1-72.

Nadlinger K., Meneguz B., Apollonio M., Marco I. and Harlt G. B. 1992. Molecular systematics of ibex in western Europe. Proceedings of the Congreso Internacional del género Capra en Europa. Ronda, Málaga. Octubre 1992. (in press)

Martínez T. 1988. Comparación de los hábitos alimentarios de la cabra montés y de la oveja en la zona alpina de Sierra Nevada. Archivos de Zootecnia 37: 39-49.

Martínez T. 1990. Régimen alimentario de la cabra montés (Capra pyrenaica) en la zona alpina de Sierra Nevada durante los meses de Julio y Agosto. Ecología 4: 177-183.

Rodríguez M. 1969. La cabra montés en Sierra Nevada. Ministerio de Agricultura, Documentos Técnicos, Madrid: 1-95.

Valle F. 1985. Mapa de series de vegetación de Sierra Nevada (España). Ecologia Mediterranea 11: 183-199.

Received 25 November 1993, revised 10 June 1994, accepted 15 June 1994. 